\title{
Erratum to: Art in Science: Orthopaedics Through Philatelic Material
}

\author{
Sarper Gursu MD, Timur Yildirim MD, \\ Vedat Sahin MD, Emine Tok
}

Published online: 13 December 2013

(C) The Association of Bone and Joint Surgeons ® 2013

Erratum to: Clin Orthop Relat Res (2013) 471:3755-3759

DOI 10.1007/s11999-013-3280-4

In the published study by Gursu and colleagues, Emine

Tok's surname was incorrectly written as Koç.

The authors apologize for the error.

The online version of the original article can be found under doi:10.1007/s11999-013-3280-4.

S. Gursu ( $₫)$, T. Yildirim, V. Sahin

Baltalimani Metin Sabanci Bone and Joint Diseases Education

and Research Hospital, 34730 Istanbul, Turkey

e-mail: sarper154@yahoo.com

E. Tok

Department of Arts History, Faculty of Literature,

Ege University, Izmir, Turkey 